\title{
The Physicochemical Properties of Tempe Protein Isolated from Germinated and Non-Germinated Soybeans
}

\author{
Made ASTAWAN $^{1}$, Tutik WreSDIYATI ${ }^{2}$, Rachel M YOSHARI ${ }^{1}$, \\ Nikita Arsy RACHMAWATI ${ }^{1}$ and Rahma FADILLA ${ }^{1}$ \\ ${ }^{1}$ Department of Food Science and Technology, Faculty of Agricultural Engineering and Technology, \\ Bogor Agricultural University, Indonesia \\ ${ }^{2}$ Department of Anatomy, Physiology, and Pharmacology, Faculty of Veterinary Medicine, \\ Bogor Agricultural University, Indonesia
}

(Received June 13, 2019)

\begin{abstract}
Summary Tempe is an indigenous Indonesian source of protein. In this study, the tempe was produced from Grobogan soybeans with two types of treatment, germinated and nongerminated. The two types of tempe produced were then processed into protein isolates, tempe protein isolate from non-germinated soybeans (NGTI) and tempe protein isolate from germinated soybeans (GTI). This study was aimed to compare the physicochemical properties of NGTI, GTI, and CSI (commercial soy protein isolate). Seen from the physical characteristics, the NGTI and GTI were superior to CSI in their bulk density which was very significantly higher $(p<0.01)$ at $0.54,0.57$ and $0.39 \mathrm{~g} / \mathrm{mL}$, respectively, and the $\mathrm{a}_{\mathrm{w}}$ value which was very significantly lower $(p<0.01)$ at $0.05,0.04$ and 0.34 , respectively. As for the chemical characteristics, the NGTI and GTI were superior to CSI in their protein content which was very significantly higher $(p<0.01)$ at $79.16,82.89$ and $74.90 \%$, respectively, the in vitro protein digestibility which was also significantly higher $(p<0.05)$ at $76.95,77.82$ and $76.68 \%$, respectively, and the fat content which was very significantly lower $(p<0.01)$ at $1.45,1.28$, and $2.74 \%$, respectively.
\end{abstract}

Key Words bulk density, protein digestibility, $\mathrm{a}_{\mathrm{w}}$ value, germination, protein isolate

Protein isolates have a great prospect as either a main ingredient or a supporting ingredient in the food industry. A protein isolate is the purest form of a protein with a protein content of $90 \%$ and is nearly free from carbohydrates, fibers, and fats (1). The high protein content gives protein isolates a very important role improving the functional properties of food products such as the water holding capacity, solubility, emulsion-forming ability, gel-forming ability, and foaming characteristic (2). The advantage of protein isolates is that they have high digestibility and can be mixed with other ingredients without causing significant changes in sensory properties (3-5).

The Indonesian Central Bureau of Statistics revealed that in 2013 Indonesia imported 1,192,173 tons of protein isolates to fulfill the food industry's demands (6). This situation is, of course, ironic as Indonesia has an abundance of protein sources, especially plant-based proteins, which have the potential to be developed as protein isolates, namely legumes and cereals.

Soybeans are the main source of plant-based protein for Indonesian people who usually consume them in the form of tempe and tofu. Tempe is a traditional food from Indonesia which is a product of soybean fermentation by the mold Rhizopus spp. (7). Compared to soybeans, the nutrients in tempe are more easily digested, absorbed, and utilized by the body because the fermenta-

E-mail: astawan@apps.ipb.ac.id; mastawan@yahoo.com tion process improves the nutrient components in soybeans. As for the quality and bioavailability, tempe proteins are simpler and have higher solubility, making them easier for the body to absorb and utilize. In addition, anti-nutrients such as trypsin inhibitors are suppressed during the fermentation process of the soybeans $(8)$.

Every year Indonesia is forced to import 2,087,986 tons of soybeans to fulfill $71 \%$ of the national soybean demand (9). To increase the national soybean production, many superior soybean varieties have begun to be developed, including the local Grobogan variety soybean. The study has demonstrated that quality of Grobogan variety soybeans can compete with imported soybeans as the raw ingredient for tempe (10). One of the innovations that can be done to improve the quality of tempe is by modifying the raw materials, for example through germinating the soybeans.

The germination process was selected because it is an applicative technology which is relatively affordable to improve the nutrient quality of cereals and legumes. The protein content increases by approximately $4 \%$, while carbohydrate and lipid decrease by approximately 5-6\% (11). Germination of soybeans can increase the total dissolved protein and decrease the concentration of anti-nutrient compounds $(12,13)$.

According to Mahmoud et al. (14), soybean germination has benefits, namely: 1) increasing the content of vitamin $\mathrm{B} 2$, vitamin $\mathrm{C}$, and calcium bioavailability; 2) 
increasing the digestibility of proteins, 3) hydrolyzing oligosaccharides that can cause flatulence, 4) decreasing the content of anti-nutritive compounds such as trypsin inhibitors, phytic acid, and lectins; 5) decreases the activity of the lipoxygenase enzyme which causes unpleasant odor, 6) increases antioxidant activity due to an increase in phenolic components, isoflavones aglycones, and glycosides saponins.

This study was conducted to assess the physicochemical properties of the tempe protein isolates made from soybeans and germinated soybeans. The results were then compared with a commercial soy protein isolate which was available on the market and the standard properties of soy protein isolates according to Codex. Therefore, the superiority and the short-comings of the physicochemical properties of tempe protein isolates produced in this study may be discovered.

\section{MATERIALS AND METHODS}

Materials and equipment. The materials used in producing the tempe protein isolate were local soybeans from the Grobogan variety, tempe starter (Raprima ${ }^{\mathrm{TM}}$ ), plastic packaging (food grade $\mathrm{PP} / \mathrm{PE}$ ), distilled water, filter paper, hexane, $\mathrm{NaOH}$, and $\mathrm{HCl}$. The materials used for the physicochemical property analyses were acetone, potassium hydrogen phthalate, $\mathrm{NaOH}, \mathrm{HCl}, \mathrm{Na}-$ tartrate, Na-carbonate, $\mathrm{K}_{2} \mathrm{SO}_{4}, \mathrm{HgO}, \mathrm{H}_{2} \mathrm{SO}_{4}, \mathrm{Na}_{2} \mathrm{~S}_{2} \mathrm{O}_{3}$, $\mathrm{H}_{3} \mathrm{BO}_{3}$, a phenolphthalein indicator (PP), an MR-MB indicator, and a multiple enzyme solution consisting of trypsin, chymotrypsin, and peptidase. The equipment used in producing the tempe protein isolate was a slicer, steamer, cabinet dryer, disc mill, magnetic stirrer, centrifuge, $\mathrm{pH}$ meter, and freeze dryer.

Soybean germination. The germination process was performed as described before (15). The germination process began with sorting and washing the soybeans. The soybeans were soaked in water at a ratio of $1: 5$ $(\mathrm{b} / \mathrm{v})$ for three hours. After the soaking, the soybeans were incubated for $\pm 20 \mathrm{~h}$ in the dark and watered every four hours. The germinated soybeans produced had radicula $\pm 0.5 \mathrm{~cm}$ long (Fig. 1).

Tempe production. The tempe was produced according to the procedure made by Rumah Tempe Indonesia (16). The production of tempe from soybeans and germinated soybeans was conducted separately. For the tempe from soybeans, the process began with soybean sorting, followed by soaking in water for 2-4 h and boiling for $30 \mathrm{~min}$. The boiled soybeans were then soaked again in clean water for 15-20 h. After the target $\mathrm{pH}$ (3.5-5.2) was achieved, the soybeans were dehulled. The dehulled soybeans were washed, rinsed with hot water, drained, and cooled down. After the soybeans were cool, they were inoculated with $0.2 \%$ commercial tempe starter and packed in PP plastic bags that had been perforated at an interval of $2 \mathrm{~cm}$. The process was continued with fermentation for $\pm 40 \mathrm{~h}$. A similar process was conducted for tempe from germinated soybeans, the only difference being that the process began with boiling the germinated soybeans for $30 \mathrm{~min}$.

Tempe flour production. The production of tempe

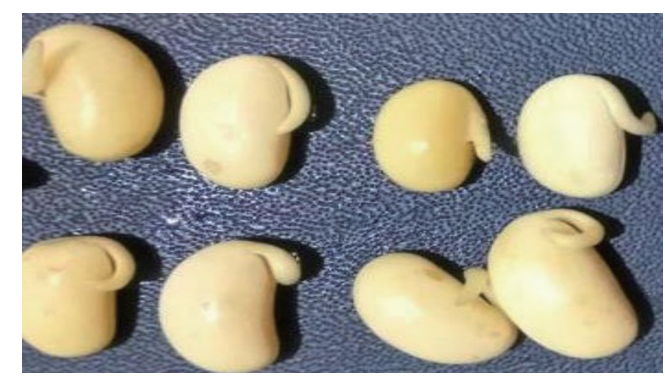

Fig. 1. Germinated soybeans.

flour began with slicing the fresh tempe using a slicer, then blanching the slices with a steamer for $2 \mathrm{~min}$, then drying them using a cabinet dryer at $60^{\circ} \mathrm{C}$ for $8 \mathrm{~h}$. The dried tempe was then ground using a disc mill with a 60 mesh sieve.

Tempe protein isolate production. The protein isolate production was conducted as described before (17). The low-fat tempe flour sample was dissolved in water (1: $10, \mathrm{w} / \mathrm{v})$ at room temperature, then had the nitrogen extracted at a $\mathrm{pH}$ between 11 and 13 (with the addition of $2 \mathrm{~N} \mathrm{NaOH}$ ) for $2 \mathrm{~h}$. The solution was centrifuged at 3,000 $\times g$ for $10 \mathrm{~min}$ at a temperature of $4^{\circ} \mathrm{C}$. The $\mathrm{pH}$ of the supernatant was adjusted so that it reached its isoelectric point (with the addition of $2 \mathrm{~N}$ $\mathrm{HCl}$ ), extracted again for two hours at a temperature of $4^{\circ} \mathrm{C}$ and centrifuged at 3,000 $\times g$ for $10 \mathrm{~min}$ at the same temperature. The sediment was rinsed with distilled water $(1: 1)$ and centrifuged again. The sample was dissolved with distilled water $(1: 1)$, had its $\mathrm{pH}$ neutralized to 7 with $2 \mathrm{~N} \mathrm{NaOH}$ at room temperature, then dried using a freeze dryer.

Protein isolate yield. The percentage of yield was calculated based on the tempe protein isolate obtained compared to the dry soybeans used (the raw material).

Proximate analysis. The proximate analyses included the contents of moisture, ash, fat, protein, carbohydrate (by difference), and crude fiber (18).

Color analysis and whiteness index. The color analysis and whiteness index were determined as described before using a chroma meter (Konica Minolta CR-310) (19). The data from the color measurement results were Hunter L, a, and b. The results of the color analysis using the chroma meter could be used for measuring the whiteness index using the following equation:

$\mathrm{WI}=100-((100-\mathrm{L}) 2+(\mathrm{a}) 2+(\mathrm{b}) 2) 1 / 2$

Notes:

WI: Whiteness Index

L: Brightness parameter

a: Red-green mixture chromatic color

b: Blue-yellow mixture chromatic color

Bulk density analysis. The bulk density analysis was performed as described before (20). The isolate sample was placed in a $10 \mathrm{~mL}$ graduated cylinder that had its weight recorded. The graduated cylinder containing the sample was tapped repeatedly $>30$ times until its volume was constant and there were no air bubbles when the sample was measured at $10 \mathrm{~mL}$ exactly. The measured volume was then weighed. The bulk density was 
stated as the sample mass $(\mathrm{g})$ per sample volume $(\mathrm{mL})$.

Water activity. The measurement of the water activity $\left(a_{w}\right)$ was conducted using an $a_{w}$ meter. One gram of the sample was placed the $\mathrm{a}_{\mathrm{w}}$ meter holding container. The $\mathrm{a}_{\mathrm{w}}$ and temperature would be shown after the word "completed" was displayed on the equipment display screen.

In vitro protein digestiblity analysis. The in vitro protein digestibility was assessed as described before (21). A number of samples were suspended in distilled water to the concentration of $6.25 \mathrm{mg}$ protein $/ \mathrm{mL}$. An amount of $25 \mathrm{~mL}$ of the sample suspension was placed in a small beaker glass then the $\mathrm{pH}$ was adjusted to 8 . The sample was then put inside a water bath set at $37^{\circ} \mathrm{C}$ for $5 \mathrm{~min}$ and stirred. An amount of $2.5 \mathrm{~mL}$ of the multienzyme solution was added (the moment when the enzymes were added was recorded as time zero) to the sample suspension while stirring in the $37^{\circ} \mathrm{C}$ water bath. The $\mathrm{pH}$ of the sample suspension was recorded at precisely the 10th min. The protein digestibility was stated as the equation

$\mathrm{Y}=210.464-18.103 \mathrm{x}$,

where $\mathrm{Y}=$ Protein digestibility and

$\mathrm{x}=$ the $\mathrm{pH}$ at the 10 th $\mathrm{min}$.

Experimental design. The data were processed using the SPSS 20.0 program with One-Way ANOVA test and a follow-up test with Duncan's test at a confidence level

Table 1. The yield of products based on the soybean dry weight.

\begin{tabular}{lrc}
\hline \multirow{2}{*}{ Yield (\%) } & \multicolumn{2}{c}{ Type of treatment } \\
\cline { 2 - 3 } & Soybeans & $\begin{array}{c}\text { Germinated } \\
\text { soybeans }\end{array}$ \\
\hline Tempe & $154.5 \pm 3.0^{\mathrm{a}}$ & $163.1 \pm 2.9^{\mathrm{b}}$ \\
Tempe flour & $61.4 \pm 1.2^{\mathrm{a}}$ & $60.7 \pm 1.6^{\mathrm{a}}$ \\
Defatted flour 1 & $52.4 \pm 1.6^{\mathrm{a}}$ & $49.9 \pm 1.9^{\mathrm{a}}$ \\
Defatted flour 2 & $48.9 \pm 1.7^{\mathrm{a}}$ & $47.6 \pm 2.5^{\mathrm{a}}$ \\
Protein Isolate & $18.5 \pm 1.0^{\mathrm{a}}$ & $22.9 \pm 0.0^{\mathrm{a}}$ \\
\hline
\end{tabular}

of 0.95 .

\section{RESULTS}

Yield

The data of yield is shown in Table 1. Tempe has high yield and it is shown statistically that the germination process very significantly $(p<0.01)$ influenced the tempe yield. The tempe flour yield was decrease as well as the defatted flour. The process of isolating the protein from defatted tempe flour resulted in a relatively low final yield (18.5-22.9\%).

Chemical characteristics

The data in Table 2 revealed that the germination process significantly $(p<0.05)$ influenced the proximate composition of the tempe protein isolate. The statistical test results also demonstrated that NGTI and GTI had similar moisture contents, but both were significantly lower $(p<0.05)$ than that of CSI. Meanwhile, the statistical test results demonstrated that the CSI and NGTI samples had similar ash contents, but both were significantly lower $(p<0.05)$ than that of GTI. As for the protein content, statistical tests demonstrated that the germination process and fermentation of soybeans very significantly $(p<0.01)$ influenced the samples' protein content. The protein content of GTI was higher than that of CSI. The NGTI and GTI fat content were similar to one another, but both were very significantly lower $(p<0.01)$ than that of CSI. The results of Duncan's multiple range test demonstrated that the carbohydrate contents of CSI and NGTI were not significantly different from each other but both were significantly higher $(p<0.05)$ than that of GTI. The statistical test results revealed that the crude fiber contents of CSI and GTI were not significantly different from one another but they were both significantly higher $(p<0.05)$ than that of NGTI. The crude fiber contents of the tempe protein isolates (GTI and NGTI) and commercial soy protein isolate (CSI) were still above the CODEX standard.

Color characteristics

Table 3 presents the results of the analysis of the color physical property in the tempe protein isolates (NGTI and GTI) compared to the commercial soy pro-

Table 2. The comparison of the proximate composition of the tempe protein isolates, commercial soy protein isolate, and Codex standard (30).

\begin{tabular}{|c|c|c|c|c|}
\hline \multirow{2}{*}{ Parameter } & \multicolumn{3}{|c|}{ Type of isolate } & \multirow{2}{*}{$\begin{array}{l}\text { CODEX } \\
\text { Standard }\end{array}$} \\
\hline & CSI & NGTI & GTI & \\
\hline Moisture (\%wb) & $4.26 \pm 0.02^{\mathrm{b}}$ & $2.18 \pm 0.67^{\mathrm{a}}$ & $2.10 \pm 0.58^{\mathrm{a}}$ & $<10 \%$ \\
\hline Ash (\%db) & $5.17 \pm 0.03^{a}$ & $5.23 \pm 0.39^{a}$ & $6.44 \pm 0.36^{\mathrm{b}}$ & $<8 \%$ \\
\hline Fat $(\% \mathrm{db})$ & $2.86 \pm 0.02^{b}$ & $1.48 \pm 0.12^{\mathrm{a}}$ & $1.31 \pm 0.22^{\mathrm{a}}$ & - \\
\hline Protein (\%db) & $78.23 \pm 0.05^{\mathrm{a}}$ & $80.92 \pm 1.17^{\mathrm{ab}}$ & $84.65 \pm 0.73^{b}$ & $>90 \%$ \\
\hline Carbohydrate (\%db) & $13.74 \pm 0.03^{b}$ & $12.37 \pm 2.10^{\mathrm{b}}$ & $7.60 \pm 0.29^{\mathrm{a}}$ & - \\
\hline Crude fiber $(\% \mathrm{db})$ & $1.20 \pm 0.01^{\mathrm{b}}$ & $0.84 \pm 0.11^{\mathrm{a}}$ & $1.08 \pm 0.01^{\mathrm{b}}$ & $<0.05 \%$ \\
\hline
\end{tabular}

$\mathrm{CSI}=$ Commercial soy protein isolate, $\mathrm{NGTI}=$ Non-germinated soybean tempe protein isolate, GTI $=$ Germinated soybean tempe protein isolate. Values on the same row that are followed by different superscript letters mark significantly different results $(p<0.05)$ with the One Way ANOVA test. 
Table 3. The physical properties of tempe protein isolate and commercial soy protein isolate.

\begin{tabular}{lcrr}
\hline & & Type of Isolate & \\
\cline { 2 - 4 } \multicolumn{1}{c}{ Parameter } & CSI & NGTI & GTI \\
\hline L & $61.36 \pm 0.01^{\mathrm{c}}$ & $54.74 \pm 0.34^{\mathrm{b}}$ & $52.06 \pm 0.64^{\mathrm{a}}$ \\
$\mathrm{a}$ & $1.50 \pm 0.04^{\mathrm{a}}$ & $2.02 \pm 0.00^{\mathrm{a}}$ & $1.88 \pm 0.40^{\mathrm{a}}$ \\
$\mathrm{b}$ & $12.66 \pm 0.00^{\mathrm{ab}}$ & $13.88 \pm 0.01^{\mathrm{b}}$ & $11.24 \pm 0.54^{\mathrm{a}}$ \\
Whiteness index $(\%)$ & $59.31 \pm 0.01^{\mathrm{b}}$ & $52.62 \pm 0.33^{\mathrm{a}}$ & $50.72 \pm 0.49^{\mathrm{a}}$ \\
Bulk density $(\mathrm{g} / \mathrm{mL})$ & $0.39 \pm 0.00^{\mathrm{a}}$ & $0.54 \pm 0.02^{\mathrm{b}}$ & $0.57 \pm 0.02^{\mathrm{b}}$ \\
Water activity $\left(\mathrm{a}_{\mathrm{w}}\right)$ & $0.34 \pm 0.01^{\mathrm{b}}$ & $0.05 \pm 0.01^{\mathrm{a}}$ & $0.04 \pm 0.00^{\mathrm{a}}$
\end{tabular}

Values on the same row that are followed by different superscript letters mark significantly different results $(p<0.05)$ with the One Way ANOVA test.

Table 4. The in vitro protein digestibility of the tempe protein isolates and commercial soy protein isolate.

\begin{tabular}{cccc}
\hline & & \multicolumn{2}{c}{ Type of Isolate } \\
\cline { 2 - 4 } Parameter & CSI & NGTI & GTI \\
\hline Protein digestibility & $76.68 \pm 0.00^{\mathrm{a}}$ & $76.68 \pm 0.00^{\mathrm{a}}$ & $76.68 \pm 0.00^{\mathrm{a}}$ \\
\hline
\end{tabular}

Values on the same row that are followed by different superscript letters mark significantly different results $(p<0.05)$ with the One Way ANOVA test.

tein isolate (CSI) as the control. The results of the statistical test revealed that germination had a significant effect $(p<0.01)$ on the color physical property, except for the red-green chromatic color parameter. The three samples were very significantly different $(p<0.01)$ from one another in terms of brightness level. CSI had a higher brightness level than both NGTI and GTI. As for the whiteness index parameter, the NGTI and GTI samples were similar, but both were very significantly lower $(p<0.01)$ than that of CSI. For the yellow chromatic color, the statistical test results demonstrated that GTI was very significantly lower $(p<0.01)$ yellow chromatic color than NGTI.

Bulk density characteristic

For the protein isolate bulk density, statistical test results in Table 3 revealed that NGTI and GTI were similar to one another, but both were very significantly higher $(p<0.01)$ than CSI.

Water activity characteristic

The data in Table 3 revealed that the results of the statistical test for NGTI and GTI's water activity $\left(\mathrm{a}_{\mathrm{w}}\right)$ were similar to one another, but both were very significantly lower $(p<0.01)$ than that of CSI.

In vitro protein digestibily

The results of the in vitro protein digestibility analysis for the tempe protein isolates and commercial soy protein isolate are presented in Table 4 . The results of the statistical test demonstrated that the germination and fermentation processes significantly $(p<0.05)$ influenced the protein digestibility of the samples. The GTI's protein digestibility was significantly higher than those of CSI and NGTI.

\section{DISCUSSION}

\section{Yield}

The high tempe yield was due to the process of soybean soaking at the beginning of the tempe production (Table 1). The germination process caused the tempe yield to be higher than tempe from non- germinated soybeans. This was because during the germination process the soybeans absorbed the surrounding moisture for their metabolic processes, thus increasing the moisture content (22).

Values on the same row which are followed by different superscript letters mark significantly different results $(p<0.05)$ with the Paired Samples $t$-test.

The next stage was processing the tempe into tempe flour. The tempe flour yield decreased due to the slicing using the slicer and the drying in the oven. During the slicing, a lot of the tempe adhered to the slicer. The oven drying caused a significant decrease in the moisture content due to evaporation, reducing the weight which had a role in decreasing the yield.

The next process was reducing the fat content (defatting) of the tempe flour. This process is important in the production of protein isolates. Protein has a hydrophilic side which can bind fats which means that a high fat content could interfere with the protein extraction process (23). The fat content of tempe flour is fairly high, $25.02 \%$ in non-germinated soybean tempe flour and $23.10 \%$ in germinated soybean tempe flour (24); this is why the defatting process could reduce the yield. The process of isolating the protein from defatted tempe flour resulted in a relatively low final yield (18.5$22.9 \%$ ). This was because the protein isolation principle 
involves an extraction process, the removal of non- solubles through centrifugation, sedimentation, rinsing, and drying, thus it could significantly reduce the yield (Table 1).

Chemical characteristics

The data in Table 2 showed that the germination process affected the proximate composition of the tempe protein isolate. The results also revealed that NGTI and GTI statistically had similar moisture contents, but both were lower than that of CSI. The lower moisture content in NGTI and GTI was due to the soaking, germination, and fermentation processes of the soybeans which caused an increased permeability of the cell walls. This facilitated water diffusion and the exit of soluble components out of the material (25).

The ash content of a food material is the total minerals contained in it (26). The results statistically demonstrated that the CSI and NGTI samples had similar ash contents, but both were lower than that of GTI. The high ash content in GTI was due to the germination process which could decrease the content of a number of antinutrients which had a positive effect on increasing the dissolved mineral content (27). As for the protein content, the results demonstrated that the germination process and fermentation of soybeans influenced the samples' protein content.

The protein content of GTI was higher than that of CSI. This was because the germination process could decrease the content of other components, thus increasing the protein content (23). The germination process causes the protein content to increase by $4 \%$, whereas the carbohydrate and lipid contents decreased by 5-6\% (11). Tempe as the raw material for the protein isolate underwent a boiling and fermentation process which caused the removal of dissolved components and the consumption of non- protein compounds by the mold which increased the protein content (28).

The protein content of the three protein isolates (GTI, NGTI, and CSI) in this study was not yet able to reach the required protein content in the CODEX standard which is greater than $90 \%$. This was perhaps due to the protein isolation process which was not effective enough. However, the commercial soy protein isolate (CSI) had a protein content which did not fulfill the standard and tended to be lower than those of the tempe protein isolate samples (GTI and NGTI).

The NGTI and GTI fat content were similar to one another, but both were lower than that of CSI. Fat is the main energy source for the growth of the results statistically demonstrated that the carbohydrate contents of CSI and NGTI were not different from each other but both were higher than that of GTI. This was due to the fat and carbohydrate degradation during the germination process. The tempe mold, so during the fermentation process the mold's lipase activity would break fat down into free fatty acids and the fermentation process could reduce the fat by up to $26 \%$ (29).

The results statistically demonstrated that the carbohydrate contents of CSI and NGTI were not different from each other but both were higher than that of GTI.
This was due to the fat and carbohydrate degradation during the germination process. The purpose of the degradation is to provide energy needed for the synthesis of new proteins. Therefore, it can be said that the germination process has a beneficial effect (11).

Fiber is a group of indigestible polysaccharides in food such as cellulose, hemicellulose, and lignin. Crude fiber is the residue of food treated with boiling acid and alkali (31). The results revealed that the crude fiber contents of CSI and GTI statistically were not different from one another but they were both higher than that of NGTI. The fermentation process is accompanied by the growth of mold mycelia which could increase the crude fiber content due to the formation of cell walls which contain cellulose (32); therefore, logically, NGTI and GTI should have a higher fiber content than CSI.

The crude fiber contents of the tempe protein isolates (GTI and NGTI) and commercial soy protein isolate (CSI) were still above the CODEX standard. During fermentation, Rhizopus spp. mycelia have multiple nuclei and fibrous walls which might account for the increased fiber contents in NGTI and GTI (33).

Color characteristics

Table 3 presents the results of the analysis of the color physical property in the tempe protein isolates (NGTI and GTI) compared to the commercial soy protein isolate (CSI) as the control. The results revealed that germination statistically had an effect on the color physical property, except for the red-green chromatic color parameter. The three samples statistically were different from one another in terms of brightness level. CSI had a higher brightness level than both NGTI and GTI. As for the whiteness index parameter, the NGTI and GTI samples were similar, but both statistically were lower than that of CSI. For the yellow chromatic color, the results demonstrated that GTI statistically was lower yellow chromatic color than NGTI. This was probably caused by the soybean fermentation and germination processes which could affect the stability of the natural pigments in soybeans.

\section{Bulk density characteristic}

For the protein isolate bulk density, the results in Table 3 revealed that NGTI and GTI were similar to one another, but both were statistically higher than CSI. This was because the fermentation process in the making of tempe can trigger the enzyme system to break down complex molecules (protein, carbohydrate, and fat) into simpler (34). This caused the size of the NGTI and GTI particles to be smaller and more densely packed. A higher density flour would be more efficient in packaging. Therefore, GTI and NGTI would be more efficient in shipping and storage compared to CSI.

Water activity characteristic

Water activity $\left(\mathrm{a}_{\mathrm{W}}\right)$ is a parameter commonly used as a food safety and quality criterion. Water activity can also be defined as the amount of free water in the food material in which in certain conditions could be utilized by microbes for their growth and might render the food unsuitable for consumption. The data in Table 3 revealed that the results for NGTI and GTI's water activ- 
ity $\left(\mathrm{a}_{\mathrm{w}}\right)$ were similar to one another, but both were lower than that of CSI. This was probably due to the difference in each sample's particle size.

During the fermentation and germination process, there is a breaking down of various complex molecules into simpler forms, leading to smaller particle sizes. A smaller particle size is believed to make the particles be more densely packed in occupying space volume, reducing the interaction between water vapor in the air and reduces the flour's ability to absorb moisture from the air (35). Products dried with a freeze dryer usually have a moisture content of approximately $2-8 \%$ and $\mathrm{a}_{\mathrm{w}}$ of approximately $0.1-0.25$ or less (36). The flour's lower water activity is advantageous because it would have a relatively longer shelf life.

In vitro protein digestibily

The assessment of the protein digestibility in this study used the multienzyme technique with conditions as similar as possible to protein digestion in the body. The enzyme used was a mixture of trypsin, chymotrypsin, and peptidase.

The results of the in vitro protein digestibility analysis are presented in Table 4 . The results demonstrated that the germination and fermentation processes influenced the protein digestibility of the samples. The GTI's protein digestibility was higher than those of CSI and NGTI. This was because GTI underwent the germination and fermentation processes. The germination process could eliminate enzyme- inhibiting activities such as the trypsin inhibitor which could increase the protein digestibility. The germination process also triggered an increase in protease activity in breaking down large protein molecules into smaller and simpler amino acids. Simpler protein molecules would make it easier for the protease to digest and hydrolyze, leading to a better protein digestibility.

The fermentation process undergone by tempe could improve the quality and bioavailability of the protein because there had been protein degradation due to the mold's proteolytic activities which broke down the protein into simpler forms. The simpler protein structure increased the protein solubility, making it easier for the body to absorb and utilize (16).

In conculusion, the soybean germination process and fermentation of tempe influenced the chemical and physical characteristics and the protein digestibility of the tempe protein isolates. The fat content of the tempe protein isolates (GTI and NGTI) was significantly lower than that of the commercial soy protein isolate (CSI). The protein content of GTI was significantly higher than that of CSI.

The bulk density of NGTI and GTI was significantly higher than that of CSI. On the other hand, the water activity $\left(\mathrm{a}_{\mathrm{w}}\right)$ of NGTI and GTI was significantly lower than that of CSI. GTI's protein digestibility was significantly higher than that of the other two protein isolates.

\section{Disclosure of state of COI}

The author(s) declared no potential conflicts of inter- est with respect to the research, authorship, and/or publication of this article.

\section{Acknowledgments}

The writers would like to thank the Directorate General of Research and Development Strengthening, the Ministry of Research, Technology, and Higher Education of the Republic of Indonesia that had funded this study through the "Penelitian Berbasis Kompetisi 2019" listed under Made Astawan.

\section{REFERENCES}

1) Oktasari T, Suparmi, Rahman K. 2015. Manufacture isolates protein of carp (Osphronemus gouramy) with different $\mathrm{pH}$ methods. JOM 2(2): 1-12.

2) Kinsella JE. 1976. Functional properties of protein in foods: a survey of critical reviews. Food Sci Nutr 7: 219280.

3) Codex Alimentarus. 1989. General Standard For Soy Protein Products.

4) Garba U, Kaur S. 2014. Review-protein isolates: Production, functional, properties, and application. International Research Journal Consortium 4: 22-36.

5) Mignone LE, Wu T, Horowitz M, Rayner CK. 2015. Whey protein: The "whey" forward for treatment of type 2 diabetes? World J Diabetes 6(14): 1274-1284.

6) Witono Y, Anam C, Herlina, Pamujiati AD. 2014. Chemical and functional properties of protein isolate from cowpea (Vigna unguiculata). IJASEIT 4(2): 58-62.

7) Astawan M, Hermanianto J, Suliantari, Sugiyanto GSP. 2016. Application of vacuum packaging to extend the shelf life of fresh- seasoned tempe. Int Food Res J 23(6): 2571-2580.

8) Astawan M, Wresdiyati T, Sirait J. 2015. Pengaruh konsumsi tempe kedelai grobogan terhadap profil serum, hematologi, dan antioksidan tikus. J Teknol Indust Pangan 26(2): 155-162.

9) [Kementan] Kementerian Pertanian RI. 2015. Outlook Kedelai 2015. Jakarta (ID): Pusat Data dan Infromasi Pertanian.

10) Astawan M, Wresdiyati T, Widowati S, Bintari SH, Ichsani N. 2013. Karakteristik fisikokimia dan sifat fungsional tempe yang dihasilkan dari berbagai varietas kedelai. J Pangan 22(3): 241-252.

11) Shi H, Nam PK, Ma Y. 2010. Comprehensive profiling of isoflavones, phytosterols, tocopherols, minerals, crude protein, lipid, and sugar during soybean (Glycine $\max$ ) germination. J Agric Food Chem 58(8): 49704976.

12) Zielinski H. 2003. Contribution of low molecular weight antioxidants to the antioxidant screen of germinated soybean seeds. Plant Foods Hum Nutr 58(1): 1-20.

13) Marton ZM. 2010. The Role of sprouts in human nutrition. Acta University Sapientiae Alimentaria 3: 81-117.

14) Mahmoud MH, Taha MM, Shahy EM. 2016. Germination of Glycine $\max$ seeds potentiates its antidiabetic effect in streptozotocin induced diabetic rats. Int J Pharm Clin Res 8(10): 1429-1437.

15) Puteri NE, Astawan M, Palupi NS. 2017. Karakteristik tepung tempe larut air. J Pangan 26(2): 117-126.

16) Astawan M, Wresdiyati T, Maknun L. 2017. Tempe Sumber Zat Gizi dan Komponen Bioaktif untuk Kesehatan. Bogor (ID): IPB Press.

17) Liu C, Wang X, Ma H, Zhang Z, Gao W, Xiao L. 2008. 
Functional properties of protein isolates from soybean stored under various conditions. Food Chem 111(1): 29-37.

18) $[\mathrm{AOAC}]$ Association of Official Analytical Chemistry. 2012. Official Method of Analysis. Gaithersburg (US): AOAC.

19) Hutching John. B. 1999. Food Color and Appearance. Second Edition. Maryland: Aspen Publisher, Inc.

20) Adeleke RO, Odedeji JO. 2010. Functional properties of wheat and sweet potato flour lends. Pakistan J Nutr 9(6): 535-538.

21) Hsu HW, Vavak DL, Satterlee LD, Miller GA. 1977. A multienzyme technique for estimating protein digestibility. JFS 42(5): 1269-1273.

22) Ojha P, Karki TB, Maharjan S. 2014. Effect of sprouting in physicochemical properties of tofu. J Nutr Health Food Eng 1(2): 1-8.

23) Astawan M, Wahyuni M, Yamada K, Tadokoro T, Maekawa A. 1995. Defatting and desalting treatments of Indonesian dried-salted fish: dietary effects on alpha-tocopherol and peroxide levels in serum and liver of rats. Biosci Biotechnol Biochem 59(8): 1450-1454.

24) Astawan M, Wresdiyati T, Ichsan M. 2016. Karakteristik fisikokimia tepung tempe kecambah kedelai. J Gizi Pangan 11(1): 35-42.

25) Faridah DN, Kusnandar F, Herawati D, Kusumaningrum HD, Wulandari N, Indrasti D. 2008. Analisis Pangan. Bogor (ID): Departemen Ilmu dan Teknologi pangan IPB.

26) Osman MA. 2007. Effect of different processing methods on nutrient composition, antinutritional factors, and in vitro protein digestibility of dolichos lablab bean (Lablab purpureus (L) Sweet). Pakistan J Nutr 6(4): 299 303.

27) Reyes-Bastidas M, Reyes-Ferna'ndez, López- Cervantes, Milán-Carrillo J, Loarca-Pin GF, Reyes-Moreno C. 2010. Physicochemical, nutritional and antioxidant properties of tempe flour from common bean (Phaseolus vulgaris L.). Food Sci Tech Int 16(5): 427-428.

28) Astuti M, Andreanyta M, Dalais SF, Wahlqvist ML. 2000. Tempe, a nutritious and healthy food from Indonesia. Asia Pacific J Clin Nutr 9(4): 322-325.

29) $[\mathrm{CAC}]$ Codex Alimentarius Commission. 1989. Codex General Standard for Soy Protein Products. Roma (IT): Food and Agriculture Organization of the United Nations World Health Organization.

30) Kusnandar F. 2010. Komponen Makro Kimia Pangan. Jakarta (ID): Dian Rakyat.

31) Rahayu ES, Indrati R, Utami T, Harmayani E, Cahyanto MN. 1993. Bahan Pangan Hasil Fermentasi. Yogyakarta (ID): PAU Pangan dan Gizi.

32) Pelezar MJ, Reed RD. 1997. Microbiology. New York (US): Mc Graw Hill Book Co. Westport, Connecticut.

33) Elkhalifa AEO, Bernhardt R. 2010. Influence of grain germination on functional properties of sorghum flour. Food Chem 121: 387-392.

34) Troller JA, Christian JHB. 1978. Water Activity and Food. New York (US): Academy Press.

35) Astawan M, Wahyuni M, Yamada K, Tadokoro T, Maekawa A. 1994. Changes in protein nutritional quality of Indonesia dried-salted fish after storage. J Sci Food Agric 66(2): 155-161. 